\title{
Chemical variability of water and sediment over time and along a mountain river subjected to natural and human impact
}

\author{
Ewa Szarek-Gwiazda ${ }^{1, *}$, Grażyna Mazurkiewicz-Boroń ${ }^{2}$, Robert Gwiazda ${ }^{1}$ and Jan Urban ${ }^{1}$ \\ ${ }^{1}$ Institute of Nature Conservation, Polish Academy of Sciences, Krakow, Poland \\ ${ }^{2}$ Institute of Environmental Engineering, The John Paul II Catholic University of Lublin, Stalowa Wola, Poland
}

\begin{abstract}
We studied the variability of physico-chemical parameters in water, and heavy metal contents in water and sediment over time and along the Carpathian Biała Tarnowska River (southern Poland) and related them to catchment geology, human impact and the effect of barriers as a side aspect. The river water was well oxygenated, had $\mathrm{pH}$ 7.7-9.5 and was characterised by low and average flow. Temperature, $\mathrm{pH}$ and dissolved oxygen did not change significantly, while the contents of major ions, $\mathrm{NO}_{3}{ }^{-}, \mathrm{NH}_{4}{ }^{+}, \mathrm{Mn}$ and Fe increased gradually along the river. The major ion contents were negatively, and nitrate, $\mathrm{Mn}$, and $\mathrm{Fe}$ positively, correlated with the flow. We recognise correlations between nitrate, $\mathrm{Fe}$ and $\mathrm{Mn}$ to be good indicators of soil erosion processes in the catchment. River sediment was unpolluted by most of the studied metals (slightly polluted by $\mathrm{Ni}$ and $\mathrm{Cd}$ ). The differences in the values of some parameters $\left(\mathrm{pH}\right.$ and $\mathrm{NH}_{4}{ }^{+}$, $\mathrm{PO}_{4}{ }^{3-}, \mathrm{HCO}_{3}{ }^{-}, \mathrm{Mn}, \mathrm{Cd}$ and $\mathrm{Pb}$ concentrations) in the water, and heavy metals in the sediment upstream and downstream of some of the barriers were determined. Spatiotemporal changes in the values of studied parameters and the results of statistical calculation indicate the impact of human activity in the catchment basin (land use, wastewater) on the water chemistry.
\end{abstract}

Keywords: physico-chemical parameters / heavy metals / small barriers / catchment geology / human impact

\begin{abstract}
Résumé - Variabilité chimique de l'eau et des sédiments dans le temps et le long d'une rivière de montagne soumise à des impacts naturels et humains. Nous avons étudié la variabilité des paramètres physico-chimiques dans l'eau et les teneurs en métaux lourds dans l'eau et les sédiments au fil du temps et le long de la rivière des Carpathes Biała Tarnowska (sud de la Pologne) et nous les avons mis en relation avec la géologie du bassin versant, l'impact humain et l'effet des barrages comme aspect secondaire. L'eau de la rivière était bien oxygénée, avait un $\mathrm{pH}$ de 7,7 à 9,5 et se caractérisait par un débit faible et moyen. La température, le $\mathrm{pH}$ et l'oxygène dissous n'ont pas changé de façon significative, tandis que la teneur en ions majeurs, $\mathrm{NO}_{3}{ }^{-}, \mathrm{NH}_{4}{ }^{+}, \mathrm{Mn}$ et $\mathrm{Fe}$ ont augmenté progressivement le long de la rivière. Les teneurs en ions majeurs étaient corrélées négativement avec le débit et les nitrates, le Mn et le Fe positivement. Nous identifions les corrélations entre nitrates, Fe et Mn comme de bons indicateurs des processus d'érosion du sol dans le bassin versant. Les sédiments fluviaux n'étaient pas pollués par la plupart des métaux étudiés (légèrement pollués par le $\mathrm{Ni}$ et le $\mathrm{Cd}$ ). Les différences dans les valeurs de certains paramètres $(\mathrm{pH}$ et concentrations en $\mathrm{NH}_{4}{ }^{+}, \mathrm{PO}_{4}{ }^{3-}, \mathrm{HCO}_{3}{ }^{-}, \mathrm{Mn}, \mathrm{Cd}$ et $\mathrm{Pb}$ ) dans l'eau et les métaux lourds dans les sédiments en amont et en aval de certains barrages ont été déterminées. Les changements spatio-temporels des valeurs des paramètres étudiés et les résultats des calculs statistiques indiquent l'impact de l'activité humaine dans le bassin versant (utilisation des sols, eaux usées) sur la chimie de l'eau.
\end{abstract}

Mots-clés : paramètres physico-chimique / métaux lourds / petites barrières / géologie du drainage / impact humain

\footnotetext{
*Corresponding author: szarek@iop.krakow.pl
} 


\section{Introduction}

According to the River Continuum Concept, longitudinal changes in physical parameters, such as geomorphological and hydrological characteristics, along drainage basins is overlain by biological adaptation along these gradients in stream and rivers (Vannote et al., 1980; Cummins et al., 1995; Wetzel, 2001). The physical parameters and biological communities change along a drainage basin in a reasonably predictable manner (Wetzel, 2001). However, human activities in the catchment basin (land use, wastewater), river channelisation (Wyżga et al., 2009, 2014) and the occurrence of barriers in the river may alter these properties. Land use is recognised as a crucial factor influencing terrestrial and aquatic environments in various regions of the world (Underwood et al., 2009; Sirami et al., 2010; Cooper et al., 2013). Catchments of the Carpathian rivers in Poland are predominated by the large grassland areas and agricultural fields (Mazurkiewicz-Boroń, 2002; Twardy et al., 2003). This leads to substantial soil erosion during long-lasting rainfalls (Lajczak, 1999) accompanied by the leaching of soil particles, organic and mineral compounds, fertilisers, nutrients and heavy metals into the rivers. The average size of denudation drainage in the catchments of lowland tributaries of the Vistula River (Poland) is $5 \mathrm{t} \cdot \mathrm{km}^{-2} \cdot \mathrm{a}^{-1}, 15-200 \mathrm{ct} \cdot \mathrm{km}^{-2} \cdot \mathrm{a}^{-1}$ in the forested Beskid catchments (Carpathian area) and $200-300 \mathrm{t} \cdot \mathrm{km}^{-2} \cdot \mathrm{a}^{-1}$ in the agriculturally used Beskid catchments (Carpathian area) (Łajczak, 1999). Additional sources of contamination of Carpathian rivers in Poland are sewage from small towns and wastewater from surrounding villages without sufficient sewage treatment.

Dams and barriers are influencing most of the world's rivers. The effects of barriers on the ecological integrity of various European rivers have been intensively studied (Koster and Crook, 2008; Kemp and O'Hanley, 2010; Mueller et al., 2011; Rolls, 2011; Rolls et al., 2014, Sondermann et al., 2015; Perkin et al., 2015), obtaining information which is crucial for the successful restoration of river ecosystems. Recently, more attention has focused on the impact of small dams or weirs on biocoenosis, which is important for successful management and restoration of stream ecosystems. Mueller et al. (2011) found that weirs, through the changes in the physical habitat characteristics such as water depth, current speed, substratum composition and the transition between free-flowing water and interstitial zone upstream and downstream of the barrier, disturb the continuity of communities of the taxonomic groups of periphyton, macrophytes, macroinvertebrates and fish. Sharma et al. (2005) and Martínez et al. (2013) documented the impact of weirs on changes in physical characteristics of habitat and of benthic invertebrate communities. Lucas et al. (2008) observed disturbed movement of invertebrates upstream of the barrier. Although the adverse effects of barriers on biocoenosis are relatively well documented, less attention has been paid to abiotic factors such as the chemistry of river water and sediment. This subject is relatively well known in the case of large and medium-size dams (Kasza, 2009; SzarekGwiazda, 2013), but it is poorly studied and recognised in the case of very small dams, such as those of $2 \mathrm{~m}$ height (Mueller et al., 2011; Cisowska and Hutchins, 2016). In our study area, the Carpathian rivers in southern Poland, a large number of such small barriers have been installed.

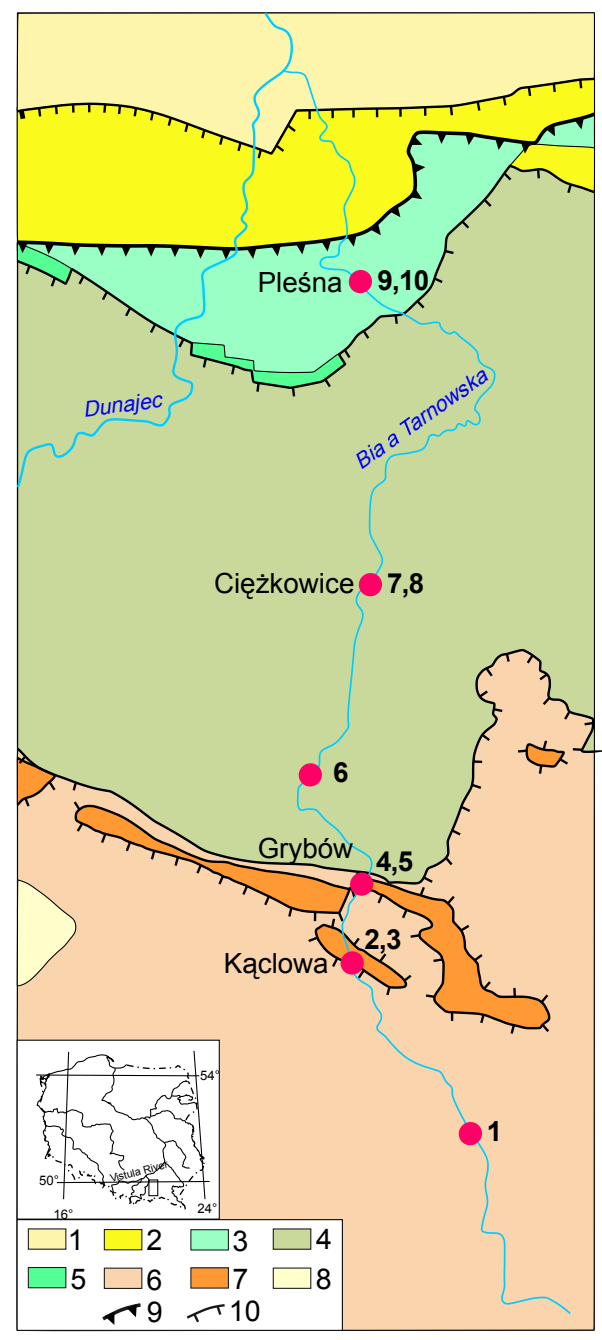

Fig. 1. Geology of the catchment and locations of the sampling pointsin the Biała Tarnowska River. (1) Neogene deposits of the Carpathians Feredeep, (2) Neogene and Paleogene Carpathian flysch deposits folded together, (3)-(8) Carpathian flysh units: (3) Skole Unit, (4) Silesian Unit, (5) Subsilesian Unit, (6) Magura Unit, (7) Grybów Unit, (8) Intramountain basins Neogene deposits, (9) Main Carpathian Overthrust, (10) Overthrusts of main tectonic units (after Alexandrowicz and Poprawa, 2000).

This study aimed to assess the variability of physicochemical water parameters and heavy metals in the water and sediment over time and along the Carpathian rivers in southern Poland. We related them to the catchment geology, human impact in the catchment (land use, wastewater) and to the possible effect of barriers as a side aspect. We hypothesised that human impact in the catchment basin and in the river (small barriers) strongly influences the variability of water and sediment chemistry over time and along a submontane river.

\section{Materials and methods}

\subsection{Study area}

The Biała Tarnowska River rises in the Beskid Niski (Carpathian belt, southern Poland) (730 ma.s.l.) and crosses 

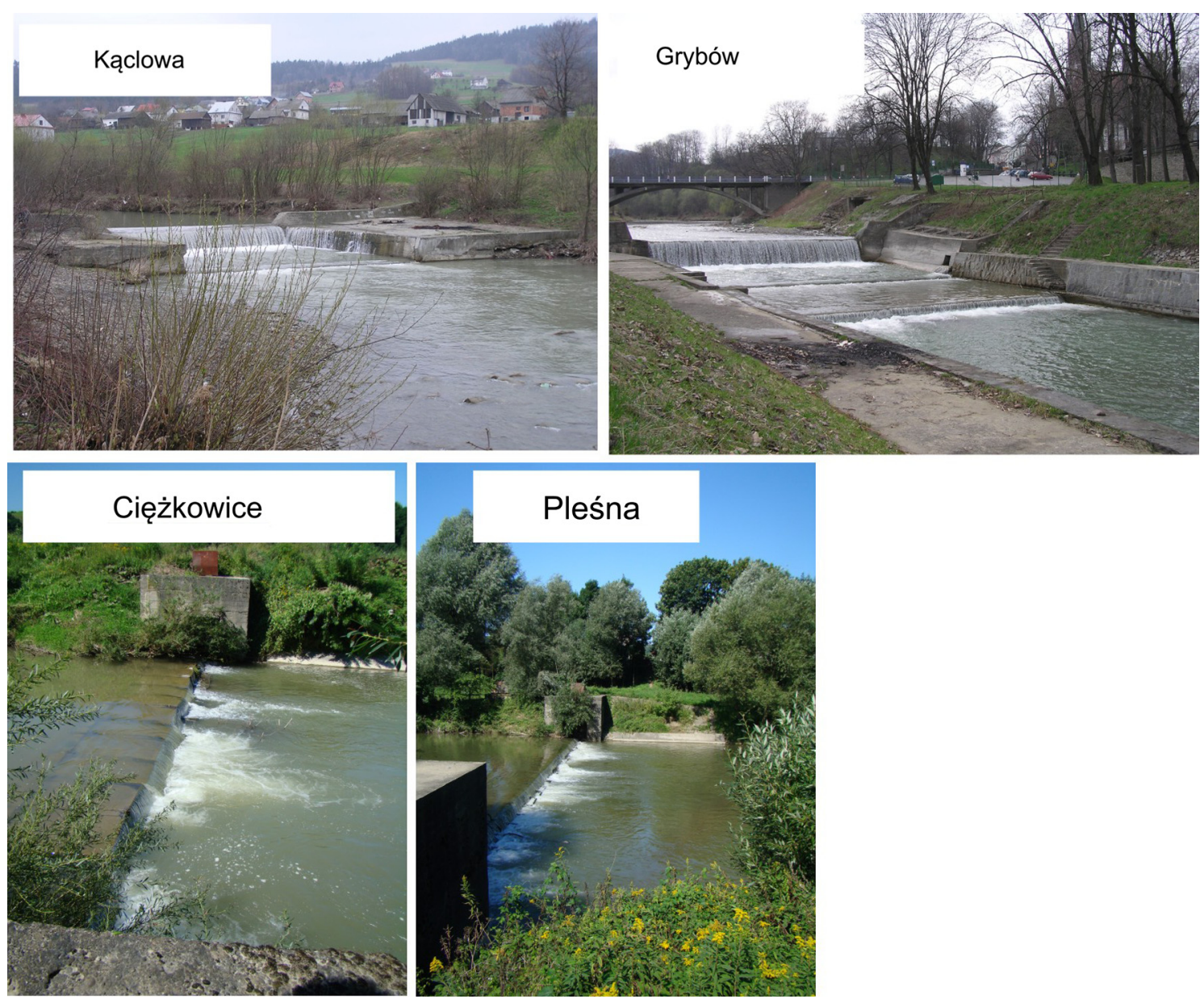

Fig. 2. Photos of the weirs in Kąclowa, Grybów, Ciężkowice and Pleśna (photos of M. Jelonek).

the Carpathian foothills downstream. It is a main tributary of the Dunajec River, a right-side tributary of the Vistula River. With a length of $101.8 \mathrm{~km}$, it features 14 barriers. In the upper and middle parts, towards the town of Grybów, the river flows through the Beskid Niski Mountains, which are formed of Cretaceous and Paleogene flysch rocks forming several large tectonic-facies units, within which many subordinate rock formations are distinguished (Fig. 1). Upstream of the town of Grybów, rocks of the Magura Unit occur, as follows: Magura Beds, formed mainly of thick-bedded sandstones, as well as Inoceramian Beds and Hieroglyphic Beds, formed of shalesandstone series with occasional marl and rare sideritic marl intercalations. In the marginal zone of the Magura Unit, a narrow outcrop of the Grybów Unit (tectonic scale), formed of siliceous-argillaceous Menilite Beds and Krosno Beds, crosses the river valley. Downstream of Grybów the substratum is formed of rocks of the Silesian Unit. A majority of the area is occupied by rock of the Krosno Beds: shale-sandstone series with occasional carbonaceous intercalations (marls, sandstones with carbonaceous cement, even limestone layers) and in some places slight dolomitic and ferruginous admixture. However, other series of the Silesian Units, such as siliceous Menilite Beds, Ciężkowice Sandstones, Istebna Beds (sandstones and shales) and Godula Beds (sandstones and shales) are also crossed by the river valley. In the lower section of the river, near Pleśna, the area is formed of rocks of the Skole Unit: shales, marls and sandstones with occasional carbonaceous cement in the Inoceramian Beds. However, in this segment of the Carpathian foothills, most of the area of flysch rock is covered with Quaternary loess sheets (Cieszkowski et al., 1991; Paul, 1991; Leszczyński and Grabowski, 1994; Kopciowski et al., 2014; Marciniec et al., 2014) (Fig. 1).

A large part of the river has natural, unregulated banks. In the catchment basin of its upper and middle sections, fields, pastures, meadows and natural vegetation predominate. There are no large industrial plants. The river is mainly contaminated by sewage from small towns and townships: Kąclowa, Grybów, Jankowa, Ciężkowice and Pleśna (2300, 6130, 940, 2501, 2046 inhabitants, respectively) and wastewater from surrounding villages (without sewage treatment). In Kąclowa, Grybów, Ciężkowice and Pleśna, small barriers are located (Fig. 2). The barrier in Kąclowa constituted a concrete step and was in a bad technical condition. Flood waters repeatedly flowed around the weir, which has led to almost complete destruction of the basin entrance point. As a consequence, the water flows above the weir and under its left side. At the township of Grybów, the river has a width of about $15 \mathrm{~m}$, and the barrier also constituted a concrete step which dammed the water at a height of $1.5 \mathrm{~m}$. Rock outcrops and thick boulders formed the bottom above and below the barrier; the banks below the barrier were protected by 
retaining walls. In the townships of Ciężkowice and Pleśna, the weirs dammed the water to create at each township a swimming pool, although this goal could not be achieved due to permanent damage of the steel closure flap. The study was carried out in the upper and middle part of the Biała Tarnowska River.

\subsection{Sampling}

Water samples were collected monthly from May 2009 to April 2010 from 10 stations situated along the Biała Tarnowska River; samples of the surface layer of the sediment $(0-5 \mathrm{~cm})$ were taken from the same stations in May and July 2009 (Fig. 1). Station 1 was situated in the upper part of the river below the edge of the forest and in the near vicinity of the small village of Brunary. Stations 2 and 3 (above and below the weir) were situated above the village of Kąclowa, stations 4 and 5 (above and below the weir) in the town of Grybów, station 6 below the township of Jankowa, stations 7 and 8 (above and below the weir) above the township of Ciężkowice and stations 9 and 10 (above and below the weir) in the town of Pleśna (Figs. 1 and 2). The distance between stations situated above and below the barriers was approximately $20-50 \mathrm{~m}$. Each time, water sampling started from the upper part of the river (station 1) at ca. $8.30 \mathrm{a} . \mathrm{m}$. and lasted $4-5 \mathrm{~h}$. In the collected water samples, $\mathrm{pH}$, conductivity, dissolved oxygen, major anions and cations, $\mathrm{BOD}_{5}$, and concentrations of $\mathrm{NH}_{4}{ }^{+}$and of heavy metals $(\mathrm{Cd}, \mathrm{Pb}, \mathrm{Zn}, \mathrm{Mn}, \mathrm{Fe}, \mathrm{Ni}$ and $\mathrm{Cr}$ ) were determined. The total concentrations of the above-mentioned metals in the sediment samples were analysed.

\subsection{Laboratory analysis}

Conductivity and $\mathrm{pH}$ were analysed using a WTW apparatus. Dissolved oxygen and $\mathrm{BOD}_{5}$ were determined according to the Winkler method (APHA, 1985). To analyse contents of major anions and cations, water samples were filtered through $0.45 \mu \mathrm{m}$ pore-sized syringe filters (Ministart RC 25, Sartorius Stedim Biotech GmbH, Germany) into polyethylene sample tubes. The inorganic ions $\mathrm{Cl}^{-}, \mathrm{SO}_{4}{ }^{2-}$, $\mathrm{HCO}_{3}{ }^{-}, \mathrm{NO}_{3}{ }^{-}, \mathrm{PO}_{4}{ }^{3-}, \mathrm{Na}^{+}, \mathrm{K}^{+}, \mathrm{Ca}^{2+}, \mathrm{Mg}^{2+}$ and $\mathrm{NH}_{4}{ }^{+}$were analysed within $24 \mathrm{~h}$ by ion chromatography (DIONEX ICS 1000 and IC DX 320, Dionex Corporation, Sunnyvale, USA). For metal analysis, samples of water were acidified to $\mathrm{pH}<2$ with ultrapure $\mathrm{HNO}_{3}$.

Sediment samples were dried at $105^{\circ} \mathrm{C}$, then homogenised and sieved through a $0.063 \mathrm{~mm}$ sieve. This allowed a silt-clay fraction $(0.063 \mathrm{~mm})$ to be distinguished. Three subsamples of each sample were digested in $65 \% \mathrm{HNO}_{3}$ using a Speed Wave microwave (MWS-3, Berghof, Eningen, Germany). Concentrations of $\mathrm{Cd}, \mathrm{Pb}, \mathrm{Zn}, \mathrm{Fe}, \mathrm{Mn}, \mathrm{Cr}$ and $\mathrm{Ni}$ in the water and sediment samples were measured using the AAS method (Varian 20, Varian Techtron PTY Limited, Mulgrave, Victoria, Australia).

\subsection{Statistics}

The data of the flows refer to the measuring stations in Grybów and Ciężkowice, and they were obtained from the Institute of Meteorology and Water Management National
Research Institute in Warsaw, Poland. The differences in the values of the studied parameters and heavy metal concentrations in the river water between the stations were analysed using the Kruskal-Wallis test. Spearman correlation coefficients were calculated to determine the relationship between studied parameters (river flow in Grybów was used) in the water of the Biała Tarnowska River. The significance of differences in the values of physicochemical parameters and concentrations of heavy metals in the water above and below the weirs were calculated using the Wilcoxon test. In order to estimate the contamination of the studied sediments by heavy metals, the index of geoaccumulation $\left(I_{\text {geo }}\right)$ was calculated with the Müller (1981) equation:

$$
I_{\text {geo }}=\log _{2}(\mathrm{Cn} / 1.5 \mathrm{Bn}),
$$

where $\mathrm{Cn}$ is the mean concentration of an element in the bottom sediment, and $\mathrm{Bn}$ is the geochemical background of the element in the shale (Turiekian and Wedepohl, 1961). According to values of the $I_{\text {geo }}$, Müller (1981) described seven categories of sediment contamination, from uncontaminated (category $0 ; I_{\text {geo }} \leq 0$ ) to extremely contaminated bottom sediment (category $6 ; I_{\text {geo }}>5$ ).

\section{Results}

The river was characterised by a low and average flow during sampling. In Grybów, water flow was in the range 0.4 $6.5 \mathrm{~m}^{3} \cdot \mathrm{s}^{-1}$; while in Ciężkowice, $1-11 \mathrm{~m}^{3} \cdot \mathrm{s}^{-1}$. Lower flows (below 1 and $3 \mathrm{~m}^{3} \cdot \mathrm{s}^{-1}$, respectively) were found in May, June, September, December, and February, while higher ones (above 2 and $4 \mathrm{~m}^{3} \cdot \mathrm{s}^{-1}$, respectively) in January, March, August, July. In August, three days prior to sampling, high flows (141 and $170 \mathrm{~m}^{3} \cdot \mathrm{s}^{-1}$, respectively) were observed.

\subsection{Water chemistry}

Water temperature of the Biała Tarnowska River ranged between 0.1 and $20.5^{\circ} \mathrm{C}$ and was slightly alkaline to alkaline (Tab. 1). The water was well oxygenated for most of the year, with oxygen saturation usually above $90 \%$. Only in $4 \%$ of the samples we measured lower oxygen saturation. Among anions, the ion $\mathrm{HCO}_{3}{ }^{-}$dominated, and among cations, $\mathrm{Ca}^{2+}$.

Most of the studied parameters showed spatial variability (Tab. 1, Fig. 3). Along the river, temperature changed only slightly, $\mathrm{pH}$ showed slight decrease, while dissolved oxygen content (also oxygen saturation) an irregular pattern. The abovementioned parameters did not show any statistical differences between the studied stations. The values of conductivity, and concentrations of major ions gradually increased along the river course, especially from station 6 (Grybów) onwards, and this pattern was constant during the entire year (Tab. 1; Fig. 3). The median contents of $\mathrm{Mg}^{2+}, \mathrm{K}^{+}, \mathrm{Na}^{+}, \mathrm{Ca}^{2+}, \mathrm{HCO}_{3}{ }^{-}, \mathrm{SO}_{4}{ }^{2-}$ and $\mathrm{NO}_{3}{ }^{-}$increased by $1.7-2.5$ times, while $\mathrm{Cl}^{-}$increased by 5.2 time from station 1 to station 10 . The differences in the contents of the anions and cations between the upper (especially stations 1-3) and lower (stations 7-10) parts of the river were, in most cases, statistically significant (Tab. 2). The concentrations of nutrients $\mathrm{NO}_{3}{ }^{-}$and $\mathrm{NH}_{4}{ }^{+}$also gradually increased (2.6 and 5.7 times, respectively) along the river course. In contrast, the 
E. Szarek-Gwiazda et al.: Knowl. Manag. Aquat. Ecosyst. 2018, Vol, 5

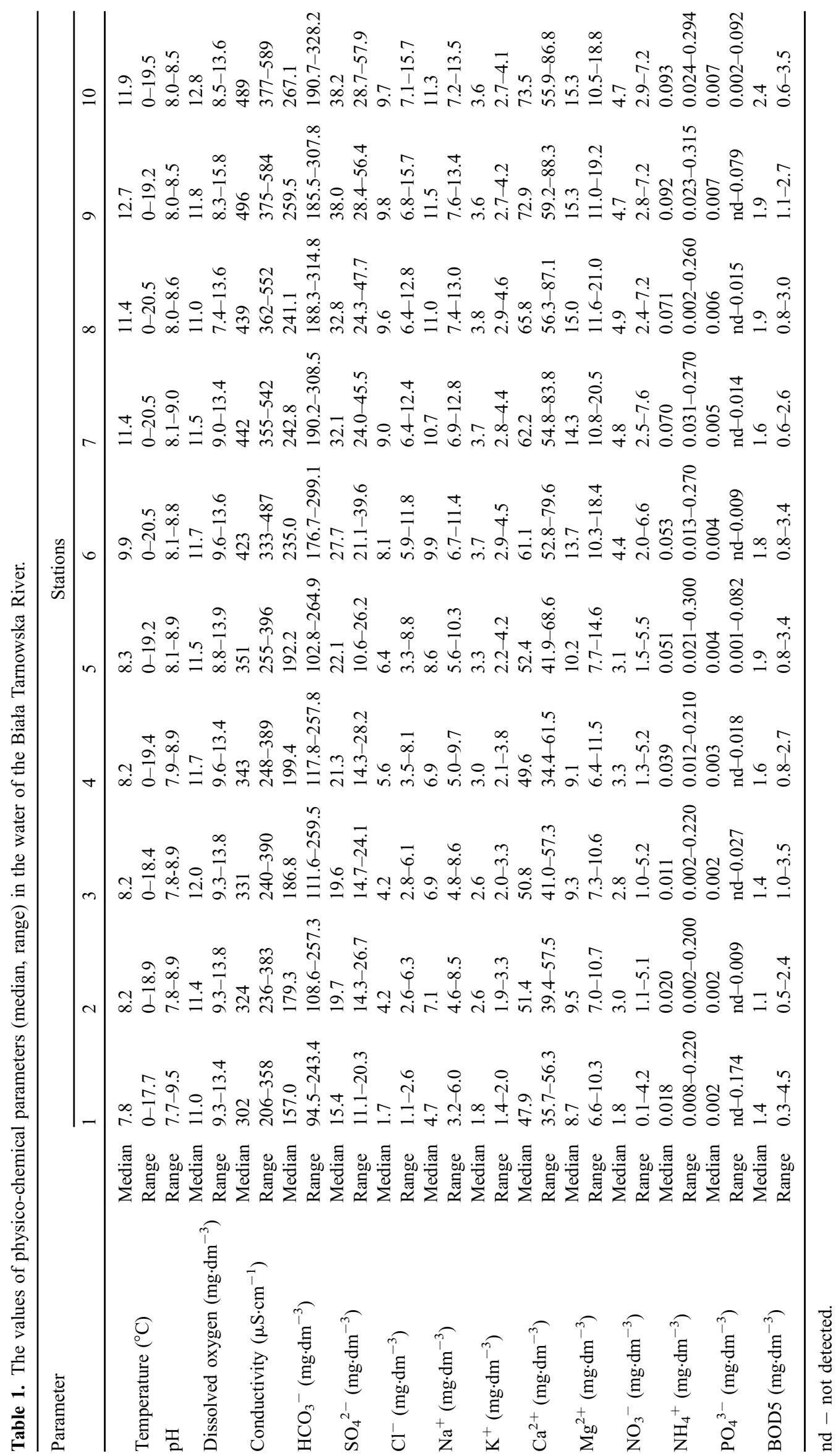


E. Szarek-Gwiazda et al.: Knowl. Manag. Aquat. Ecosyst. 2018, Vol, 5
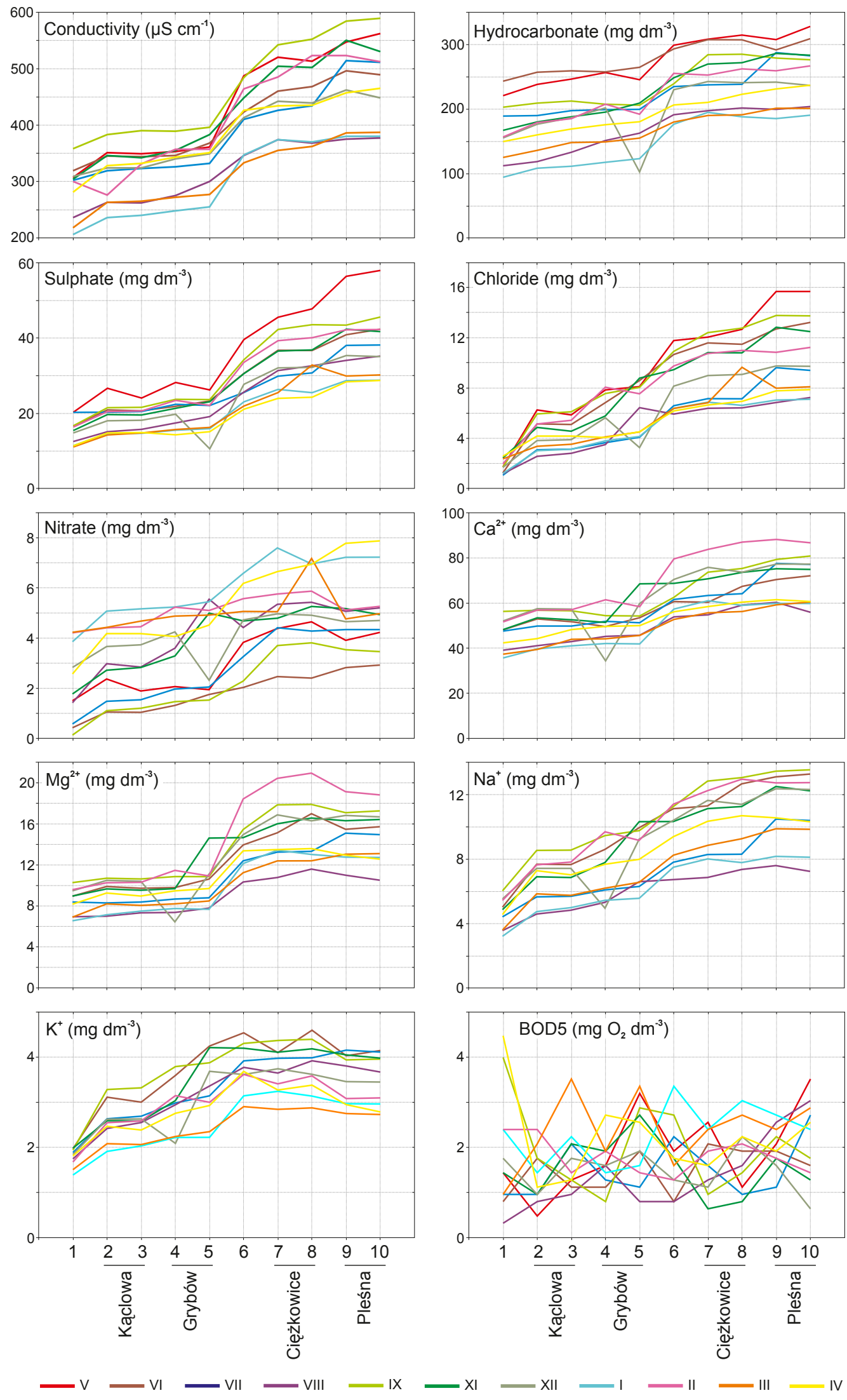

Fig. 3. Values of conductivity and physico-chemical parameters in the water at the studied stations in the Biała Tarnowska River in different months. 
Table 2. The significance of differences in the values of physicochemical parameters and heavy metal concentrations of the water between the studied stations of the Biała Tarnowska River (Kruskal-Wallis test, the value " $p$ " for multiple comparisons). Only significant differences are given.

\begin{tabular}{lll}
\hline Parameter & The value of statistics & Stations \\
\hline Conductivity & $\mathrm{H}_{9 ; 111}=76.08 ; p=0.0000$ & $6-10>1$ \\
& & $7-10>2-4$ \\
& & $9-10>5$ \\
$\mathrm{Cl}^{-}$ & $\mathrm{H}_{9 ; 111}=78.58 ; p=0.0000$ & $5-10>1$ \\
& & $7-10>2,3$ \\
& $\mathrm{H}_{9 ; 111}=39.75 ; p=0.0000$ & $10>4$ \\
$\mathrm{HCO}_{3}{ }^{-}$ & $\mathrm{H}_{9 ; 111}=82.93 ; p=0.0000$ & $9-10>1$ \\
& & $6-10>1$ \\
$\mathrm{SO}_{4}{ }^{2-}$ & $7-10>2,3,5$ \\
& & $8-10>4$ \\
$\mathrm{Na}^{+}$ & & $6-10>1$ \\
& & $8-10>3$ \\
& & $9,10>4$ \\
$\mathrm{~K}^{+}$ & $\mathrm{H}_{9,100}=58.60 ; p=0.0000$ & $5-10>1$ \\
& & $6-8>2$ \\
& & $6,8>3$ \\
$\mathrm{Ca}^{2+}$ & $\mathrm{H}_{9 ; 100}=64.07 ; p=0.0000$ & $6-10>1$ \\
& & $8-10>2,3$ \\
& & $7-10>4$ \\
& & $9>5$ \\
$\mathrm{Mg}^{2+}$ & $\mathrm{H}_{9 ; 100}=71.12 ; p=0.0000$ & $6-10>1$ \\
& & $7-10>2-4$ \\
$\mathrm{NO}_{3}{ }^{-}$ & $\mathrm{H}_{9 ; 111}=31.20 ; p=0.0003$ & $7,8,10>1$ \\
$\mathrm{NH}_{4}{ }^{+}$ & & $9,10>1-3$ \\
$\mathrm{Mn}_{9 ; 111}=64.77 ; p=0.0000$ & $9,10>1-6$ \\
& & $7,8>2,3$ \\
& & $7,9,10>3$ \\
\hline
\end{tabular}

$p-$ significance level.

values of $\mathrm{BOD}_{5}$ and $\mathrm{PO}_{4}{ }^{3-}$ contents showed an irregular pattern along the river course, although a slight increase in their median values at stations 5-10 compared to stations 1-4 was observed.

Temporal changes in the values of the studied parameters were also observed. Temperature changed during the year in a way typical for the temperate climate zone, with highest values in summer and lowest in winter. An alkaline water $\mathrm{pH}$ (above 8.5) was found at most stations from May to July and at some stations in September, November and December. The water was more highly oxygenated in winter and spring months than during summer and autumn. The lowest content of dissolved oxygen was found below the weir in Ciężkowice (station 8) in September. Both $\mathrm{pH}$ and oxygen saturation showed a weak negative correlation with the river flow (Tab. 3 ).

Temporal changes of major cation and anion contents were usually similar for each station (Fig. 3). Lower contents of major ions were found in January, March or August, and additionally of $\mathrm{SO}_{4}{ }^{2-}$ in April during the average river flow, but a higher one usually in May, June, September, November or February in the period of low water flow (with the exception of November). The contents of major anions and cations showed a strong positive correlation $(r>0.8)$ among themselves, and a weak negative correlation with the river flow (with the exception of $\mathrm{K}^{+}$ion) (Tab. 3).

Nitrate concentration was usually low during the vegetation period (Fig. 3). It was negatively correlated with $\mathrm{pH}$, temperature and oxygen saturation, but positively correlated with the river flow (Tab. 3). The value of $\mathrm{BOD}_{5}$ and $\mathrm{NH}_{4}{ }^{+}$ content showed considerable changes (BOD5 up to 14 times, $\mathrm{NH}_{4}{ }^{+}$up to 130 times) at particular stations in the studied period. The content of $\mathrm{NH}_{4}{ }^{+}$ion was positively correlated with the contents of major ions (Tab. 3). At some stations, higher contents of phosphate were found from May to July.

\subsection{Heavy metal concentrations in water}

Concentrations of heavy metals in the water of the Biała Tarnowska River were in the following ranges (in $\mu \mathrm{g} \mathrm{dm}^{-3}$ ): Cd nd-0.083, Pb 0.02-3.6, Zn nd-137, Mn 2-180, Fe 1.31068, Ni 0.1-12.3, Cr 0.1-7.6.

Median $\mathrm{Mn}$ and $\mathrm{Fe}$ concentrations gradually increased along the river (Mn 9 times, Fe 3 times, between stations 1-10) (Tab. 4). The differences in the Mn concentrations between stations $9-10$ and stations $1-6$, as well as between stations 7-8 and stations $2-3$, were statistically significant (Tab. 2). Also, the Fe concentrations at stations 7,9 and 10 were statistically higher than at station 3 (Tab. 2). Taking into consideration only the stations situated above the studied weirs, we observed a slight increase in median $\mathrm{Zn}, \mathrm{Ni}$ and $\mathrm{Pb}$ contents (from station 6) along the river, while $\mathrm{Cr}$ and $\mathrm{Cd}$ concentrations showed a less regular pattern. Higher median concentrations of $\mathrm{Cr}$ were observed in Grybów and Ciężkowice (stations 4, 5, 7 and 8), while the highest $\mathrm{Cd}$ content was measured in Pleśna (station 9) (Tab. 4).

Heavy-metal concentrations in the river water showed considerable variability over the study period (Tab. 4, Fig. 4). Higher median values of metal concentrations in the water along the river occurred in April (Cd, Zn, Mn, Ni), June (Cd), July (Cd, Mn, Fe, Cr, Ni), August (Cd, Pb, Mn, Fe, Cr, Ni), September (Pb, Zn, Ni), November ( $\mathrm{Pb}, \mathrm{Zn})$, December (Ni), January $(\mathrm{Fe}, \mathrm{Ni})$ and March $(\mathrm{Mn})$. We found positive correlations between $\mathrm{Mn}, \mathrm{Fe}, \mathrm{Cr}$ and $\mathrm{Ni}$ concentrations and the river flow. At low river flow, concentrations of most metals were usually low at most stations; for instance $\mathrm{Cd}, \mathrm{Zn}, \mathrm{Ni}$ and $\mathrm{Cr}$ in May. But also at low river flow, metal concentrations showed high variability along the river in some months; for instance, $\mathrm{Cd}, \mathrm{Pb}, \mathrm{Zn}, \mathrm{Ni}$ in September. At average river flow, a rather regular increase in the contents of some metals (for instance $\mathrm{Mn}, \mathrm{Fe}, \mathrm{Cr}, \mathrm{Ni}$ and $\mathrm{Zn}$ in August) along the river was observed (Fig. 4). We also found negative correlations between the contents of $\mathrm{Mn}$ and $\mathrm{Fe}$ and $\mathrm{pH}$, as well as between $\mathrm{Fe}$ and oxygen saturation. Positive relationships were also found between contents of metals: $\mathrm{Cd}-\mathrm{Pb}-\mathrm{Zn}$ and $\mathrm{Fe}-\mathrm{Mn}$, and between $\mathrm{Cr}-\mathrm{Ni}$ and other metals (except $\mathrm{Cr}$ and $\mathrm{Mn}$ ) (Tab. 3).

\subsection{Heavy-metal concentrations in the sediment}

Heavy-metal concentrations in the sediment of the Biała Tarnowska River were in the following ranges: Cd 0.1-0.89, $\mathrm{Pb}$ 10.7-21.8, Zn 37.6-81.7, Mn 245-755, Ni 17.5-71.3, Cr

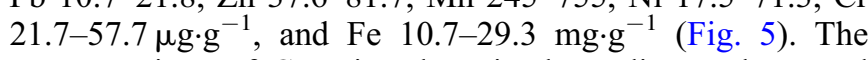
concentrations of $\mathrm{Cr}$, $\mathrm{Ni}$ and $\mathrm{Fe}$ in the sediment decreased 
E. Szarek-Gwiazda et al.: Knowl. Manag. Aquat. Ecosyst. 2018, Vol, 5

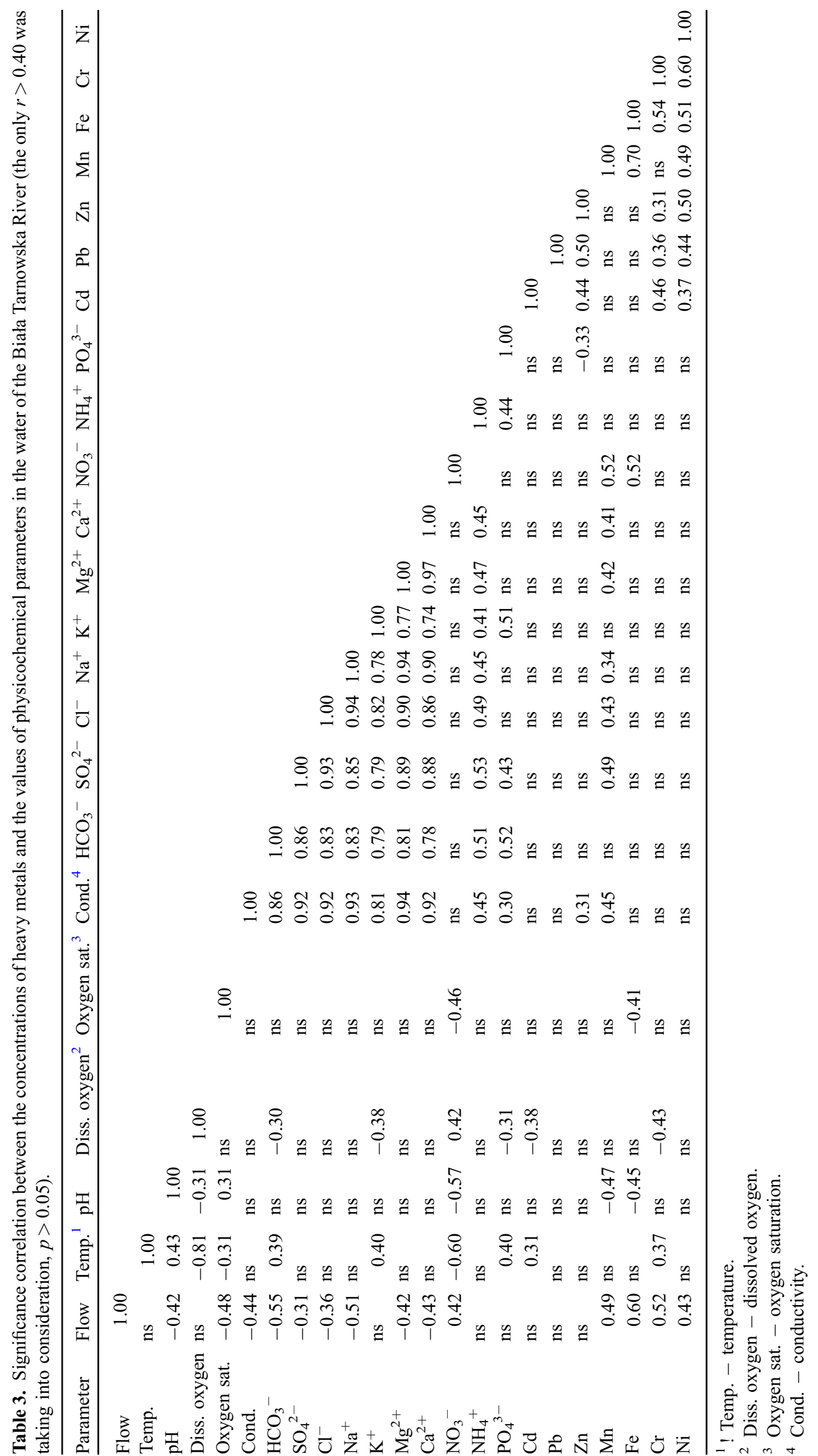




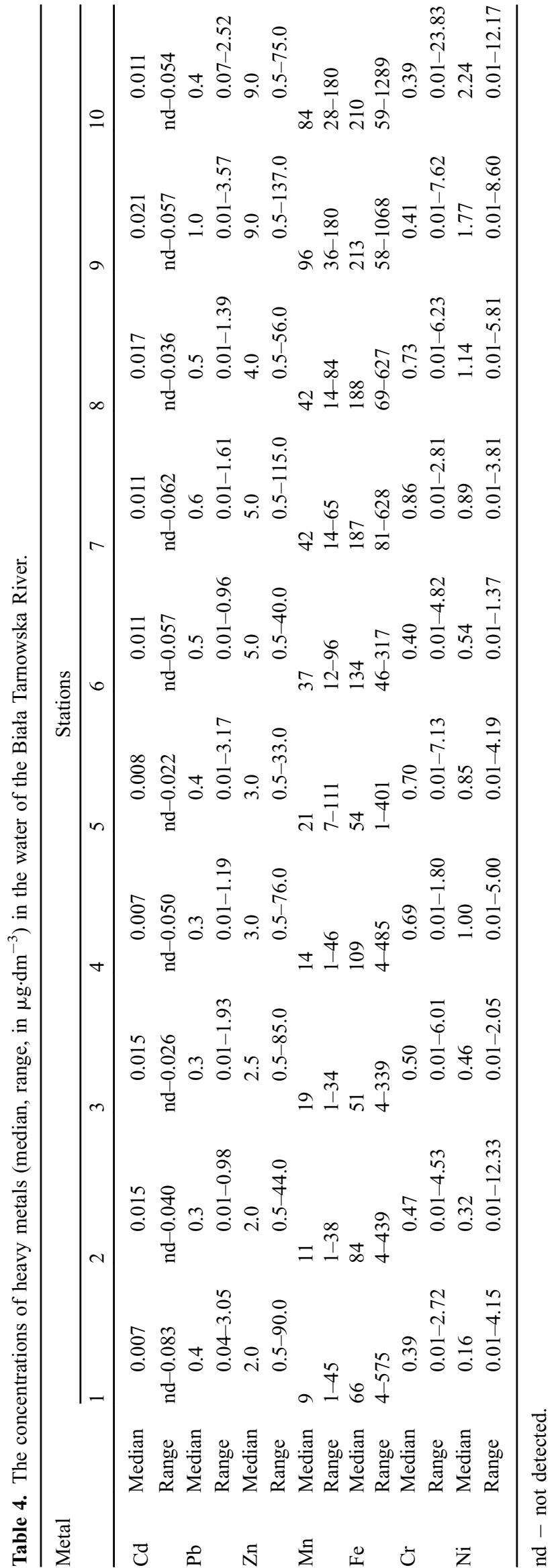

along the river course, while those of $\mathrm{Cd}, \mathrm{Pb}, \mathrm{Zn}$ and $\mathrm{Mn}$ showed irregular patterns (Fig. 5).

The values of the geoaccumulation index (Müller, 1981) indicated that at most stations, sediment was unpolluted (class $0, I_{\text {geo }} \leq 0$ ) by heavy metals. Only the sediment at station 2 was slightly polluted (class $1 ; 0<I_{\text {geo }} \leq 1.0$ ) by $\mathrm{Ni}$ and at stations 1, 2, 4-7 by $\mathrm{Cd}$.

\subsection{Barriers}

In most cases the values of physico-chemical parameters and heavy-metal contents of the water at stations situated above and below the weirs were similar (no significant differences), with a few exceptions (Tab. 5). Below the weir in Kąclowa (station 3) we found higher contents of Mn and hydrocarbonate, but below the weir in Grybów (station 5) higher conductivity values and contents of $\mathrm{NH}_{4}{ }^{+}, \mathrm{Na}^{+}$and $\mathrm{K}^{+}$ (Tab. 5). Occasionally, an inverse pattern was determined and above the weir in Kąclowa (station 2) in December higher contents of ions $\mathrm{HCO}_{3}{ }^{-}, \mathrm{Cl}^{-}, \mathrm{SO}_{4}{ }^{2-}, \mathrm{NO}_{3}{ }^{-}, \mathrm{Na}^{+}, \mathrm{K}^{+}, \mathrm{Ca}^{2+}$ and $\mathrm{Mg}^{2+}$ were measured. In Ciężkowice, higher sulphate content was found below the weir (station 8), while higher $\mathrm{pH}$ values above the weir (station 7). In Pleśna, higher phosphate content was found below the weir (station 10), but higher $\mathrm{Cd}$ and $\mathrm{Pb}$ contents above the weir (station 9) (Tab. 5). The differences in median contents of the above parameters in samples located upstream and downstream the weirs were low. For instance, the contents of Mn above and below the weir in Kaclowa were 11 and $19 \mu \mathrm{g} \cdot \mathrm{dm}^{-3}$, respectively, while contents of $\mathrm{HCO}_{3}{ }^{-}$were 179 and $187 \mathrm{mg} \mathrm{dm}^{-3}$, respectively.

In the sediment below the barrier, lower heavy metal concentration were usually determined (Kaclowa - all metals 1.4-3.5 times in May; Grybów - Cd 2.5 times in July; Ciężkowice - $\mathrm{Cd}$ and $\mathrm{Pb} 1.3-2$ times in May; Pleśna - all metals 1.6-4.1 times in July) (Fig. 5). Higher metal concentrations were found there only occasionally (Grybów - $\mathrm{Cd}, \mathrm{Pb}, \mathrm{Mn}$, and Fe 1.3-2 times in May; Ciężkowice - Cd and $\mathrm{Ni}$ 1.3-1.4 times in July). In some cases, similar metal concentrations above and below the barriers were found. Metal accumulation was higher at the Kąclowa and Pleśna barriers compared to barriers in Grybów and Ciężkowice. Among metals, $\mathrm{Cd}, \mathrm{Mn}$ and Fe were accumulated within the barriers in higher amounts than were $\mathrm{Pb}, \mathrm{Zn}$ and $\mathrm{Cr}$.

\section{Discussion}

Well-oxygenated water, of calcium bicarbonate-type, slightly alkaline and alkaline $\mathrm{pH}$, which we found in the Biała Tarnowska River is typical for Carpathian rivers in Poland (Mazurkiewicz-Boroń, 2002; Szarek-Gwiazda, 2013). Higher $\mathrm{pH}$ values obtained usually in the spring and summer, and occasionally in the winter months, accompanied by high dissolved oxygen content, which indicates intense primary production processes, are usually found in mountain rivers (Wetzel, 2001). Changes in the contents of major ions over time and along the Biała Tarnowska River could be explained by a complex impact of geological, anthropogenic and hydrological factors. The pronounced increase in major ions observed from Grybów onwards (station 6) can be related to the geological changes in the substratum, because in the vicinity of Grybów town the river valley leaves the area formed 

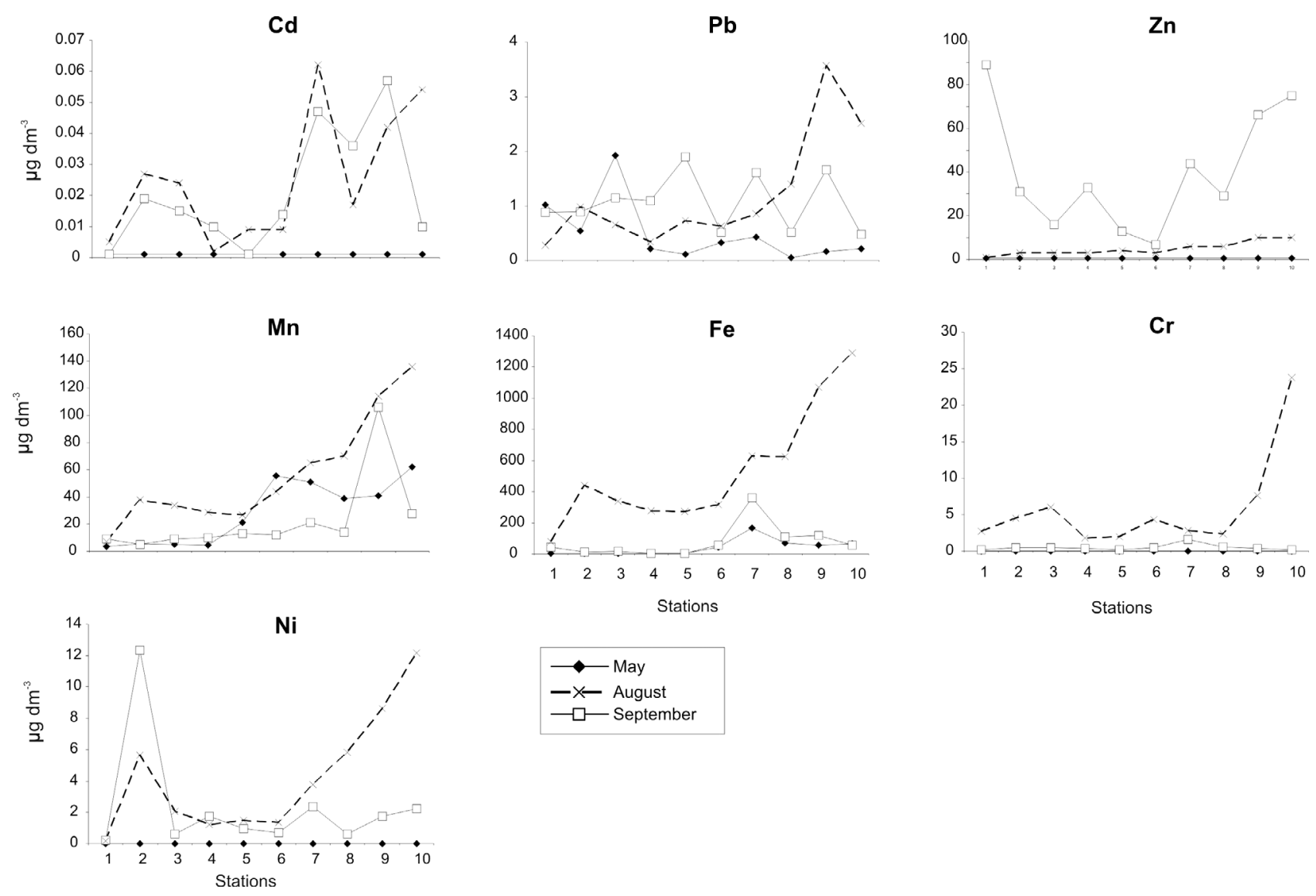

Fig. 4. The concentrations of heavy metals in the water in the Biała Tarnowska River in selected months.

of thick-bedded sandstones and the shale-sandstone series of the Magura Unit and enters the area of the more differentiated rocks of the Silesian Unit. Two reasons can probably be responsible for this observation. The first is the more abundant geochemical background of rocks of the Silesian Unit, among which carbonate intercalations with admixture of dolomitic and ferruginous (sideritic) material occur. Also, the composition of argillaceous (aluminosilicate) minerals of the Silesian Unit rocks differ from the Magura Unit (see Cieszkowski et al., 1991; Paul, 1991; Leszczyński and Grabowski, 1994; Kopciowski et al., 2014; Marciniec et al., 2014). The second reason can be related to the different weathering and, as a consequence, different water circulation in rocks of the Silesian Unit and the Magura Unit. The occurrence of thick weathering zones that cover extensive and flattened hill ridges formed usually of more clayey rocks of the Silesian Unit can favour the better leaching of elements than in the areas of the Magura Unit outcrops, with higher mountain massifs and greater content of sandstones in the substratum. The content of major ions in river water was undoubtedly also influenced by sewage from small towns and nearby villages located in the catchment area, and from diffuse sources of contamination. During low flow, when the Biała Tarnowska River was fed mainly by groundwater and the input of municipal sewage was important, a pronounced increase in the major ion contents in the water was observed (negative correlation with flow). Inversely, during average river flow (April, July, August) caused by spring thaw and the long-lasting summer rain typical for the Polish Carpathian region, which dilute wastewater, a decrease in the major ion contents of the river water was observed. The higher contents of major ions, and $\mathrm{NH}_{4}{ }^{+}$and $\mathrm{BOD}_{5}$ values in the lower part of the river indicated a deterioration of water quality of the Biała Tarnowska River.

Among nutrients, an irregular pattern of phosphate along the river and over time indicated municipal sewage to be its main source of contamination. This source is dominant in the Carpathian tributaries of the Vistula River (Twardy et al., 2003), although agriculture makes an important contribution to diffuse sources of phosphorus in various rivers (Haygarth et al., 2009). Nitrate content was dependent on the river flow (positive correlation); therefore, diffuse contamination and soil erosion was recognised as its dominant source in the Biała Tarnowska River, similar to other Carpathian rivers in Poland (Twardy et al., 2003; Szarek-Gwiazda, 2013) and in rural rivers dominated by diffuse sources of nitrate (Hutchins, 2012; Cisowska and Hutchins, 2016). Nitrates are easily leached from the soil during the spring thaw and heavy rainfall. The elements $\mathrm{Fe}$ and $\mathrm{Mn}$, which are common in the earth's crust and also leach easily from soils during heavy, persistent rains, showed positive correlation with flow and nitrate in the water of the Biała Tarnowska River. We state that the correlation Fe$\mathrm{Mn}-\mathrm{NO}_{3}$ - in the waters may be a good indicator of soil erosion processes in the catchment. An increase in the levels of $\mathrm{Fe}, \mathrm{Mn}, \mathrm{Al}$ and mineral suspension with an increase in flow rate was observed for various rivers, regardless of the type of area (rural, industrial and historically contaminated urban) in 

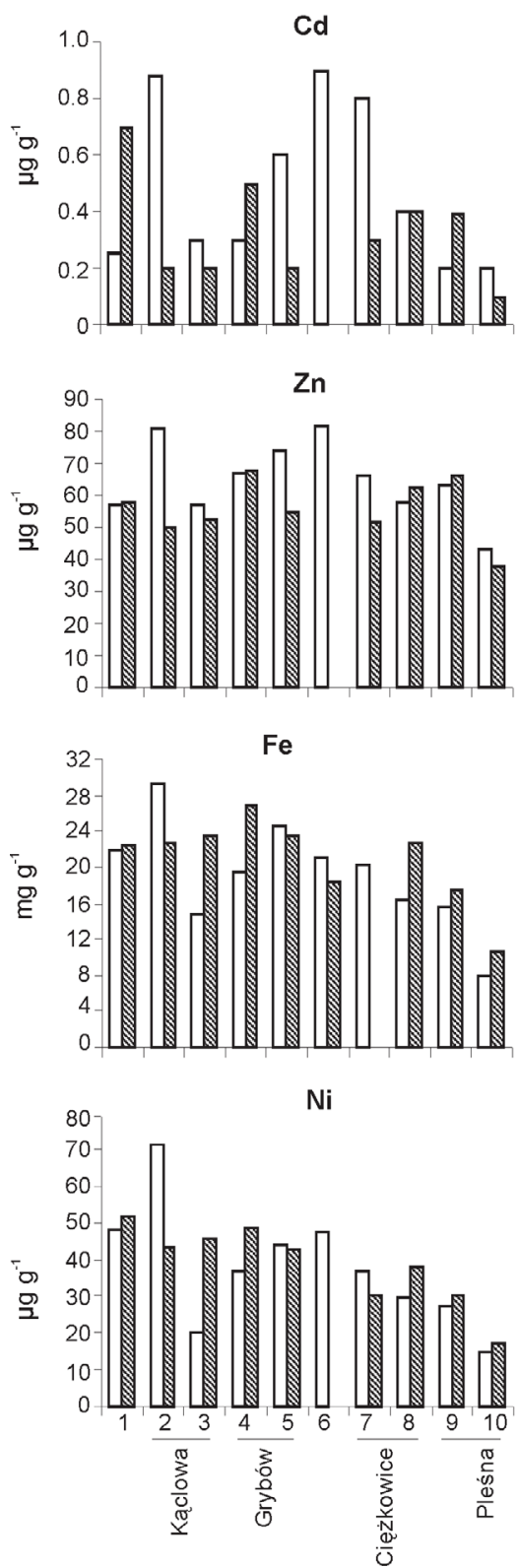
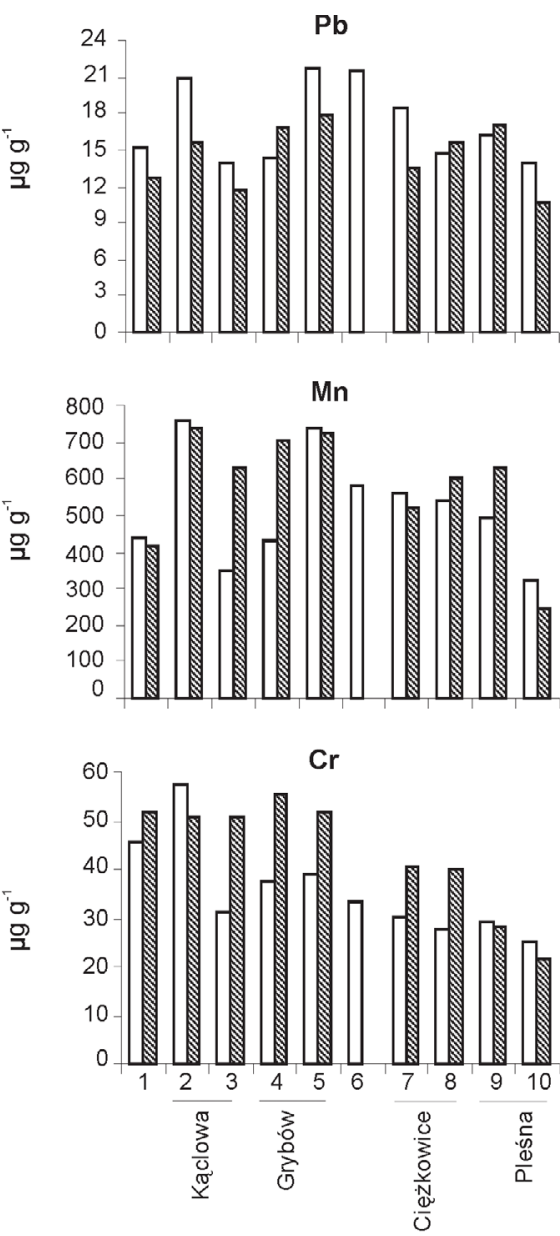

$\square$ May

Fig. 5. Concentrations of heavy metals in the sediment at the studied stations of the Biała Tarnowska River in May and July 2009.

which they were located (Neal et al., 1997). An increase of some other metals during high water flow and flood was also found in mountain streams (Abesser et al., 2006; Hardie et al., 2007). In such periods, additional sources of metals may be atmospheric precipitation or re-suspension of river sediments, which often act as 'secondary' sources of pollution (Baborowski et al., 2004; Wilber and Hunter, 2007). The contents of $\mathrm{Cr}$ and Ni were also dependent on the Biała Tarnowska River flow, indicating diffuse contamination as a dominant source. Inversely, high variability in $\mathrm{Cd}, \mathrm{Pb}, \mathrm{Zn}$, and $\mathrm{Mn}$ concentrations over time and along the river, and their positive correlation with conductivity or major ions (such as $\mathrm{Zn}$ and $\mathrm{Mn})$ may indicate sewage to be a considerable source of contamination. Strong correlations between $\mathrm{Cd}, \mathrm{Pb}$ and $\mathrm{Zn}$ were found in wastewaters (Alloway, 1995).
The concentrations of studied heavy metals in the water and sediment of the Biała Tarnowska River were small, similar to other Carpathian rivers and reservoirs (Gruca-Rokosz et al., 2004; Szarek-Gwiazda, 2013). Differences in Fe, Cr and Ni concentrations between the upper and middle parts of the river (their increase in the water and decrease in the sediment) could be explained by differences in water $\mathrm{pH}$ and their correlation with $\mathrm{Fe}$ compounds. In the river water, $\mathrm{Cr}$ and $\mathrm{Ni}$ showed a strong affinity with $\mathrm{Fe}$ (positive correlation), which is known as a redox and $\mathrm{pH}$-sensitive element (Calmano et al., 2005) and a scavenger of trace elements in various waters (Taillefert and Gaillard, 2002; Butler, 2006). In the upper part of the river, where slightly alkaline $\mathrm{pH}$ and well-oxygenated water favoured the presence of oxidised forms of $\mathrm{Fe}(\mathrm{III})$, which underwent precipitation, we found lower $\mathrm{Fe}, \mathrm{Cr}$ and $\mathrm{Ni}$ contents in water and higher ones in the sediment. In the 
Table 5. The significance of differences in the values of physicochemical parameters and concentrations of heavy metals in the water of the Biała Tarnowska River above and below the weir (Wilcoxon test). Only significant differences are given.

\begin{tabular}{llll}
\hline Barrier in: & Parametr & $Z$ & $p$ \\
\hline Kąclowa & $\mathrm{Mn}$ & 2.1 & 0.038 \\
& $\mathrm{HCO}_{3}{ }^{-}$ & 2.9 & 0.003 \\
Grybów & $\mathrm{Conductivity}$ & 2.8 & 0.005 \\
& $\mathrm{NH}^{+}$ & 2.6 & 0.010 \\
& $\mathrm{Na}^{+}$ & 2.2 & 0.028 \\
& $\mathrm{~K}^{+}$ & 2.4 & 0.017 \\
Ciężkowice & $\mathrm{pH}^{-}$ & 2.2 & 0.025 \\
Pleśna & $\mathrm{SO}_{4}{ }^{2-}$ & 2.2 & 0.026 \\
& $\mathrm{Cd}$ & 2.0 & 0.050 \\
& $\mathrm{~Pb}^{3-}$ & 2.2 & 0.026 \\
& $\mathrm{PO}_{4}{ }^{3-}$ & 2.1 & 0.033 \\
\hline
\end{tabular}

middle part, where $\mathrm{pH}$ values were lower and the process of $\mathrm{Fe}$ precipitation was probably not so efficient, we found higher contents in water and lower ones in the sediment. The potential source of $\mathrm{Cr}$ in the upper part of the river might be discharge from leather tanneries, which are widespread (ca. 300) in the Carpathian region and cause locally severe sediment contamination (Pawlikowski et al., 2006). The available geological (geochemical) data are too poor for the interpretation of the decrease in content of $\mathrm{Ni}, \mathrm{Cr}, \mathrm{Fe}$ and $\mathrm{Mn}$ in the lowest section of the river. The complex interaction of human impact, dynamics of river flow, and the physico-chemical and biological processes proceeding in the water were probably responsible for the lack of correlations in most cases between metals and the studied physico-chemical parameters.

Since the distance between the stations located above and below the barriers was not large $(20-50 \mathrm{~m})$ the possible effect of barriers on the measured parameters in the Biała Tarnowska River could not be excluded. The decrease in the $\mathrm{pH}$ values (Ciężkowice) and increased in the contents of nutrient $\left(\mathrm{NH}_{4}{ }^{+}\right.$ in Grybów; $\mathrm{PO}_{4}{ }^{3-}$ in Pleśna), and carbonate and $\mathrm{Mn}$ (Kąclowa) downstream of the barriers could be related to intensified processes of organic matter decomposition taking place in small reservoirs created above the barriers. There, a decrease in water $\mathrm{pH}$ with accompanying organic matter decomposition, could promote dissolution of carbonates and the release of $\mathrm{Mn}$ from the sediment into the overlying water. However, it should be noticed that differences in the median contents of studied parameters above and below the barriers were usually lower than the seasonal changes at a particular station. Cisowska and Hutchins (2016) found a beneficial effect of a weir in the River Nidd in Yorkshire, UK, which enhanced the removal of nitrate by denitrification, markedly more effectively in the summer when the conditions were warmer and flows lower. Mueller et al. (2011) observed the influence of weirs on the content of dissolved oxygen, temperature and $\mathrm{pH}$, which were higher in upstream samples compared to downstream, in five different rivers in Bavaria (Germany).

Physico-chemical and biological processes proceeding in small reservoirs above the barriers, combined with hydrologi- cal dynamics, probably influence the fluctuation of metal concentrations in the water and sediment above and below the studied barriers. A decrease in some heavy metal contents in water $(\mathrm{Cd}$ and $\mathrm{Pb}$ in Pleśna) and sediment (some metals in Kąclowa, Pleśna, Grybów and Ciężkowice) downstream, indicate accumulation processes proceeding in the small reservoirs above the barrier, which was conducive by low river flow. Conversely, increases in the metal concentrations downstream of the barriers (Grybów, $\mathrm{Cd}, \mathrm{Pb}, \mathrm{Mn}, \mathrm{Fe}$; Ciężkowice, $\mathrm{Cd}, \mathrm{Ni}$ ) were probably associated with high flow and sediment resuspension.

To sum up, we found the impact of geology and human activity in the catchment basin (land use, wastewater) and in the river (small barriers) on the water chemistry of the studied submontane river. The impact of barriers was relatively minor and temporary.

\section{Conclusion}

Obtained results showed the impact of human activity in the catchment basin (land use, wastewater) on the physicochemical parameters of the water, and on the content of heavy metals in water and in the sediment of a medium-sized Carpathian river. An increase in the contents of major ions along the Biała Tarnowska River and rather regular temporal changes we explained mostly by geological factors, point sources of contamination and fluctuation of river flow (negative correlation). The content of ion $\mathrm{NH}_{4}{ }^{+}$was also mostly influenced by point sources of contamination, as an increase along the river and a positive correlation with major ions were found. In contrast, as the contents of nitrate, $\mathrm{Fe}, \mathrm{Mn}$, $\mathrm{Cr}$ and $\mathrm{Ni}$ were positively correlated with the river flow, this indicates diffuse contamination to be their dominant source. We recognised the positive correlations between nitrate, $\mathrm{Fe}$ and $\mathrm{Mn}$ contents to be good indicators of soil erosion processes in the catchment. An irregular pattern of phosphate, $\mathrm{Cd}, \mathrm{Pb}$, and $\mathrm{Zn}$ distribution along the river and over time indicated municipal sewage to be their main contamination source. We found that $\mathrm{Fe}$, a scavenger of trace elements in various waters, probably influenced $\mathrm{Ni}$ and $\mathrm{Cr}$ concentrations in water and sediment in the upper and middle part of the river. The river sediment was largely unpolluted by the studied metals (except of slightly polluted by $\mathrm{Ni}$ and $\mathrm{Cd}$ at station 2). We found differences in the values of some parameters $\left(\mathrm{pH}\right.$ and $\mathrm{NH}_{4}{ }^{+}$, $\mathrm{PO}_{4}{ }^{3-}, \mathrm{HCO}_{3}{ }^{-}, \mathrm{Mn}, \mathrm{Cd}$ and $\mathrm{Pb}$ concentrations) in the water and heavy metals in sediment upstream and downstream of some of the barriers. However, the (widely understood) impact of barriers on water chemistry and heavy metals in the sediment was rather minor.

Acknowledgement. The study was partly financed by the Institute of Nature Conservation Polish Academy of Sciences, Kraków, Poland.

\section{References}

Abesser C, Robinson R, Soulsby C. 2006. Iron and manganese cycling in the storm runoff of a Scottish upland catchment. J Hydrol 326: $59-78$.

Alloway J. 1995. Heavy metals in soils, 2nd ed. London: Blackie Academic and Professional. 
Alexandrowicz Z, Poprawa D (eds). 2000. Geodoversity conservation of the Polish Carpathiansm, Warszawa: Ministerstwo S rodowiska and Państwowy Instytut Geologiczny, 142 p.

APHA. 1985. Standard methods for the examination of water and wastewater, 16th ed. Washington: American Public Health Association, $1134 \mathrm{p}$.

Baborowski M, Von Tümpling JRW, Friese K. 2004. Behaviour of suspended particulate matter (SPM) and selected trace metals during the 2002 summer flood in the river Elbe (Germany) at Magdeburg monitoring station. Hydrol Earth Syst Sci 8: 135-150.

Butler TW II. 2006. Geochemical and biological controls in trace metal transport in an acid mine impacted watershed. Environ Geochem Health 28: 231-241.

Calmano W, von der Kammer F, Schwartz R. 2005. Characterization of redox conditions in soils and sediments: heavy metals. In: Lens P, Grotenhuis T, Malina G, Tabak H, eds. Soil and Sediment Remediation. London, UK: IWA Publ, pp. 102-120.

Cieszkowski M, Koszarski A, Leszczyński S, Michalik M, Radomski A, Szulc L. 1991. Szczegółowa Mapa Geologiczna Polski 1:50000, arkusz Ciężkowice [Detailed geological map of Poland 1:50000, sheet Ciężkowice], Warszawa: Państwowy Instytut Geologiczny (in Polish).

Cisowska I, Hutchins MG. 2016. The effect of weirs on nutrient concentrations. Sci Total Environ 542: 997-1003.

Cooper SD, Lake PS, Sabater S, Melack JM, Sabo JL. 2013. The effects of land use changes on streams and rivers in mediterranean climates. Hydrobiologia 719: 383-425.

Cummins KW, Cushing CE, Minshall GW. 1995. Introduction: an overview of stream ecosystems. In Cushing CE, Cummins KW, Minshall GW, eds. River and Stream Ecosystems. Amsterdam: Elsevier, pp. 1-8.

Gruca-Rokosz R, Bartoszek L, Tomaszek JA. 2004. Heavy metals in the bottom sediments of the Solina Reservoir. Environ Pro Eng 30: $45-50$.

Hardie M, Heal KV, Lilly A. 2007. The influence of pedology and changes in soil moisture status on manganese release from upland catchments: soil core laboratory experiments. Water Air Soil Pollut 182: 369-382.

Haygarth PM, Apsimon H, Betson M, Harris D, Hodgkinson R, Withers PJA. 2009. Mitigating diffuse phosphorus transfer from agriculture according to cost and efficiency. $J$ Environ Qual 38: 2012-2022.

Hutchins MG. 2012. What impact might mitigation of diffuse nitrate pollution have on river water quality in a rural catchment? $J$ Environ Manag 109: 19-26.

Kasza H. 2009. Zbiorniki zaporowe. Znaczenie - eutrofizacja ochrona. [Dam reservoirs. Importance - eutrophication protection], Bielsko-Biała: Wydawnictwa Akademii TechnicznoHumanistycznej, $366 \mathrm{p}$.

Kemp PS, O'Hanley JR. 2010. Procedures for evaluating and prioritising the removal of fish passage barriers: a synthesis. Fisheries Manag Ecol 17: 297-322.

Kopciowski R, Zimnal Z, Chrząstowski J, Jankowski L, Szymakowska F. 2014. Szczegółowa Mapa Geologiczna Polski 1:50000, arkusz Gorlice [Detailed geological map of Poland 1:50000, sheet Gorlice], Wyd. Warszawa: Ministerstwo S rodowiska (in Polish).

Koster WM, Crook DA. 2008. Diurnal and nocturnal movements of river blackfish (Gadopsis marmoratus) in a south-eastern Australian upland stream. Ecol Freshw Fish 17: 146-154.

Łajczak A. 1999. Współczesny transport i sedymentacja materiału unoszonego w Wiśle i głównych dopływach [Contemporary transport and sedimentation of the suspended material in the
Vistula river and its tributaries]. Monogr Kom Gospod Wodnej PAN 15: 1-215 (in Polish).

Leszczyński S, Grabowski S. 1994. Szczegółowa Mapa Geologiczna Polski 1:50000, arkusz Ciężkowice [Detailed geological map of Poland 1:50000, sheet Ciężkowice], Warszawa: Państwowy Instytut Geologiczny (in Polish).

Lucas MC, Bubb DH, Jang M, Ha K, Masters JEG. 2008. Availability of and access to critical habitats in regulated rivers: effects of lowhead barriers on threatened lampreys. Freshw Biol 54: 621-634.

Marciniec P, Zimnal Z, Nescieruk P. 2014. Szczegółowa mapa geologiczna Polski 1:50000, arkusz Wojnicz [Detailed geological map of Poland 1:50000, sheet Wojnicz], Warszawa: Wyd. PIGpib (Państwowy Instytut Wydawniczy, Państwowy Instytut Badawczy) (in Polish).

Martínez A, Larrañaga A, Basaguren A, Pérez J, Mendoza-Lera C, Pozo J. 2013. Stream regulation by small dams affects benthic macroinvertebrate communities: from structural changes to functional implications. Hydrobiologia 711: 31-42.

Mazurkiewicz-Boroń G. 2002. Factors of eutrophication processes in sub-mountain dam reservoirs. Suppl Acta Hydrobiol 2: 1-68.

Mueller M, Pander J, Geist J. 2011. The effects of weirs on structural stream habitat and biological communities. J Appl Ecol 48: 1450 1461.

Müller G. 1981. Die schwermetallbelastung der sedimente des neckars und seiner nebenflüsse: eine bestandaufnahme. ChemikerZeitung. 6: 157-64.

Neal C, Robson AJ, Jeffery HA, Harrow ML, Neal M, Smith CHJ, Jarvie HP. 1997. Trace element inter-relationships for the Humber rivers: inferences for hydrological and chemical controls. Sci Total Environ 194/195: 321-343.

Paul Z. 1991. Szczegółowa mapa geologiczna Polski 1:50000, arkusz Grybów [Detailed geological map of Poland 1:50000, sheet Grybów],Warszawa: Państwowy Instytut Geologiczny (in Polish).

Pawlikowski M, Szalińska E, Wardas M, Dominik J. 2006. Chromium originating from tanneries in river sediments: a preliminary investigation from the upper Dunajec River (Poland). Pol J Environ Stud 15: 885-894.

Perkin JS, Gido KB, Cooper AR, Turner TF, Osborne MJ, Johnson ER, Mayes KB. 2015. Fragmentation and dewatering transform Great Plains stream fish communities. Ecol Monogr 85: 73-92.

Rolls RJ. 2011. The role of life-history and location of barriers to migration in the spatial distribution and conservation of fish assemblages in a coastal river system. Biol Conserv 144: 339349.

Rolls RJ, Stewart-Koster B, Ellison T, Faggotter S, Roberts DT. 2014. Multiple factors determine the effect of anthropogenic barriers to connectivity on riverine fish. Biodivers Conserv 23: 2201-2220.

Sharma CM, Sharma S, Borgstrom R, Bryceson I. 2005. Impacts of a small dam on macroinvertebrates: a case study in the Tinau River, Nepal. Aquat Ecosyst Health Manag 8: 267-275.

Sirami C, Nespoulous A, Cheylan J-P, Marty P, Hvenegaard GT, Geniez P, Schatz B, Martin J-L. 2010. Longterm anthropogenic and ecological dynamics of a Mediterranean landscape: impacts on multiple taxa. Landscape Urban Plan 96: 214-223.

Sondermann M, Gies M, Hering D, Schröder M, Feld CK. 2015. Modelling the effect of in-stream and terrestrial barriers on the dispersal of aquatic insect species: a case study from a Central European mountain catchment. Fundam Appl Limnol 186: 99-115.

Szarek-Gwiazda E. 2013. Factors influencing the concentrations of heavy metals in the Raba River and selected Carpathian dam reservoir. Studia Naturae 60: 1-146 (in Polish with English summary). 
Taillefert M, Gaillard JF. 2002. Reactive transport modeling of trace elements in the water column of a stratified lake: iron cycling and metal scavenging. J Hydrol 256: 16-34.

Turiekian KK, Wedepohl KH. 1961. Distribution of the elements in some major units of the earth's crusts. Bull Geol Soc Am 72: 175-192.

Twardy S, Kopacz M, Kostuch M, Kuźniar A, Smoroń S, Mazurkiewicz-Boroń G, Szarek-Gwiazda E, Jarząbek A, Kowalik A, Książyński KW, Sarna S, Twaróg B. 2003. Kryteria wyznaczania wód i obszarów wrażliwych na zanieczyszczenie związkami azotu pochodzącymi ze źródeł rolniczych (na terenie RZGW w Krakowie) [Criteria for the designation of waters and areas sensitive to pollution with nitrogen compounds from agricultural sources (in RZGW in Krakow)], Krakow: RZGW (in Polish).

Underwood EC, Viers JH, Klausmeyer KR, Cox RL, Shaw MR. 2009. Threats and biodiversity in the mediterranean biome. Divers Distrib 15: 188-197.
Vannote RL, Minshall GW, Cummins KW, Sedell JR, Cushing CE. 1980. The river continuum concept. Can J Fish Aquat Sci 37: 130-137. Wetzel RG. 2001. Limnology: lake and river ecosystems. 3rd ed. San Diego, San Francisko, New York, Boston, London, Sydney, Tokyo: Academic Press.

Wilber WG, Hunter JV. 2007. Aquatic transport of heavy metals in the urban environment. $J$ Am Water Resour Assoc 13: 721-734.

Wyżga B, Amirowicz A, Radecki-Pawlik A, Zawiejska J. 2009. Hydromorphological conditions, potential fish habitats and the fish community in a mountain river subjected to variable human impacts, the Czarny Dunajec, Polish Carpathians. River Res Appl 25: 517-536.

Wyżga B, Amirowicz A, Oglęcki P, Hajdukiewicz H, Radecki-Pawlik A, Zawiejska J, Mikuś P. 2014. Response of fish and benthic invertebrate communities to constrained chanel conditions in a mountain river: case study of the Biała, Polish Carpathians. Limnologica 46: 58-69.

Cite this article as: Szarek-Gwiazda E, Mazurkiewicz-Boroń G, Gwiazda R, Urban J. 2018. Chemical variability of water and sediment over time and along a mountain river subjected to natural and human impact. Knowl. Manag. Aquat. Ecosyst., 419, 5. 